Article

\title{
Hydrochemical Changes and Influencing Factors in the Dongkemadi Region, Tanggula Range, China
}

\author{
Tianding Han ${ }^{1}$, Yuping $\mathrm{Li}^{1,2}{ }^{\text {, Jia Qin }}{ }^{3, *}$, Xiangying $\mathrm{Li}^{4}$, Qin Yang ${ }^{1,2}$ and Xiaobo $\mathrm{He}^{3}$ \\ 1 State Key Laboratory of Cryosphere Science, Northwest Institute of Eco-Environment and Resources, \\ Chinese Academy of Sciences, Lanzhou 730000, China; tdhan@lzb.ac.cn (T.H.); jielantu@163.com (Y.L.); \\ yanqinyz@163.com (Q.Y.) \\ 2 College of Resources and Environment, University of Chinese Academy of Sciences, Beijing 100049, China \\ 3 Key Laboratory of Eco-hydrology Inland River Basin, Chinese Academy of Sciences, Lanzhou 730000, China; \\ hxb@lzb.ac.cn \\ 4 College of Hydrology and Water Resources, Hohai University, Nanjing 210098, China; shaanxilxy@163.com \\ * Correspondence: qinjia418@lzb.ac.cn; Tel.: +86-931-496-7395
}

Received: 6 November 2018; Accepted: 11 December 2018; Published: 14 December 2018

check for updates

\begin{abstract}
In order to detect the source and controlling factors of hydrochemical ions in glacier meltwater-recharged rivers, the chemical characteristics of the river water, precipitation, and meltwater of the Dongkemadi River Basin, China, in 2014 (from May to October) were systematically analyzed, and combined with the hydrological and meteorological data. The results show that the hydrochemical pattern of the typical river was $\mathrm{HCO}_{3}{ }^{-} \mathrm{Ca}^{2+}$. The most cations were $\mathrm{Ca}^{2+}$ and $\mathrm{Mg}^{2+}$, and the predominant anions were $\mathrm{HCO}_{3}{ }^{-}$and $\mathrm{SO}_{4}{ }^{2-}$, in the river. The concentration of major ions and total dissolved solids (TDS) in the river water were much larger than that in the precipitation and meltwater. The TDS concentration was ordered: River water $>$ precipitation $>$ meltwater. The water-rock interaction and the dilution effect of the precipitation and meltwater on the runoff ions resulted in a negative correlation between the ion concentration of the river water and the river flow. The chemical ions of the river runoff mainly originated from rock weathering and the erosion (abrasion) caused by glacier movement. In addition, the contributions of different sources to the dissolved components of the Dongkemadi River were ordered: Carbonate $(75.8 \%)>$ silicate $(15.5 \%)>$ hydatogenic rock $(5.7 \%)>$ atmospheric precipitation $(3 \%)$, calculated by a forward geochemical model. And the hydrochemical weathering rates of carbonate and silicate minerals were $12.30 \mathrm{t} \cdot \mathrm{km}^{-2} \cdot \mathrm{a}^{-1}$ and $1.98 \mathrm{t} \cdot \mathrm{km}^{-2} \cdot \mathrm{a}^{-1}$, respectively. The $\mathrm{CO}_{2}$ fluxes, consumed by the chemical weathering of carbonate and silicate, were $3.28 \times 10^{5} \mathrm{~mol} \cdot \mathrm{km}^{-2} \cdot \mathrm{a}^{-1}$ and $0.91 \times 10^{5} \mathrm{~mol} \cdot \mathrm{km}^{-2} \cdot \mathrm{a}^{-1}$, respectively.
\end{abstract}

Keywords: the Dongkemadi basin; glacier melt runoff; hydrochemistry; rate of weathering; $\mathrm{CO}_{2}$ consumption fluxes

\section{Introduction}

According to the IPCC's (Intergovernmental Panel on Climate Change) Fifth Assessment Report, the global average temperature in the past 130 years has increased by $0.85{ }^{\circ} \mathrm{C}$ [1]. As one of the most sensitive and vulnerable areas of natural ecosystems, the average temperature of the Yangtze River source in China increased by $0.32{ }^{\circ} \mathrm{C} \cdot(10 \mathrm{a})^{-1}$ during the past 50 years, which was much higher than the average increasing rate of China $\left(0.18^{\circ} \mathrm{C} \cdot(10 \mathrm{a})^{-1}\right)[2,3]$. Glacial-recharged river runoff is most sensitive to climate change, compared to the non-glacier river basins [4,5]. Glacier areas are ideal regions for studying water-rock interactions, because there are less human activities, and the chemical content of the river water here directly reflects the hydrochemical base value of the basin. Glacial areas were 
widely selected for research on terrestrial chemical erosion and biogeochemical cycle assessment [6], and had great significance for the development of hydrological chemical research in alpine regions.

There have been significant changes in alpine glaciers and river runoffs because of global warming. In western China, $82.2 \%$ of glaciers have retreated, leading to a total area loss of $4.5 \%$ [7]. The Dongkemadi Glacier in China was continuously losing mass after 1994, and this loss accelerated at the beginning of 2000 [8]. Results show that the variation of the glacier area over the period 1976-2013 is characterized by significant shrinkage at a linear rate of $-0.31 \pm 0.04 \mathrm{~km}^{2} \cdot \mathrm{year}^{-1}$. Glacier retreat slightly accelerated in the 2000s, and the mean glacier surface elevation lowered at a rate of $-0.56 \mathrm{~m} \cdot$ year $^{-1}$ over the period 2003-2008 [9]. With glaciers melting, glacial runoffs increased, and it directly changed the dissolved load caused by circulation in the basin, which in turn affected the changes of hydrochemistry and water quality in the river. Under the influence of glacial movement and high-speed erosion of meltwater, the rates of physical and chemical weathering in the glacier zone are much higher than the continental average, and this character has an important impact on the glacial environment and biogeochemical cycle $[6,10]$. At present, the research in the Dongkemadi basin mainly concentrates on glacier mass balance [11], the impact of precipitation and temperature on runoff change [12], glacial runoff simulation [13], and degree-day models [14], etc. Research of glacial hydrochemistry, especially the chemical erosion rate of glacial water and the consumption of $\mathrm{CO}_{2}$ in the Dongkemadi Basin, is rare.

Based on the water sample analysis, as well as the hydrological and meteorological data, from May to October in 2014 in the Dongkemadi Basin, the chemical characteristics and causes of the glacial runoff, precipitation, and meltwater variations were studied, and the source of water ions, the rate of hydrochemical weathering, and the $\mathrm{CO}_{2}$ consumption fluxes in the Dongkemadi basin were revealed by the qualitative and quantitative methods. This research could increase our understanding of the impact of climate change on the chemical weathering process and carbon cycle of glacial watersheds. It has significance in the evaluation of the influence of the migration and transformation of glacial-runoff solutes to the downstream water environment and ecosystem.

\section{Materials and Methods}

\subsection{Overview of the Drainage Basin}

The Dongkemadi basin is located in the source region of the Yangtze River, in China, in the hinterland of the Qinghai-Tibet Plateau, near the Tanggula Pass (Figure 1). The Dongkemadi River is a tributary of the Dangqu River, which is the source of the Yangtze River. The study area is $39.06 \mathrm{~km}^{2}$, and the controlled hydrological station is located at $92^{\circ} 00^{\prime} \mathrm{E}, 33^{\circ} 02^{\prime} \mathrm{N}$, with the elevation $5165 \mathrm{~m}$. The altitudes of the glacier area range from 5280 to $6104 \mathrm{~m}$, and the area of the glacier-covered region is about $17.15 \mathrm{~km}^{2}$, accounting for $44 \%$ of the whole basin area. Glacial meltwater accounts for $70 \%$ of the annual total runoff [13]. The annual average temperature of the Dongkemadi basin was $-5.2^{\circ} \mathrm{C}$ during the past decade, and it has been gradually rising since 1976 [9]. The summer half-year is influenced by the warm and humid air currents of the southwest Indian Ocean, while the winter half-year is controlled by the westerly circulation [12]. According to the measured data for the period 2005-2014, of the meteorological and the hydrological stations in the Dongkemadi basin, the average temperature in the period June-September was about $3.5^{\circ} \mathrm{C}$, and the precipitation was $555.7 \mathrm{~mm}$ and the runoff was $0.23 \times 10^{8} \mathrm{~m}^{3}$. The temperature, precipitation, and runoff in the glacier ablation in 2014 were $3.3^{\circ} \mathrm{C}, 475.9 \mathrm{~mm}$, and $0.24 \times 10^{8} \mathrm{~m}^{3}$, respectively. Land use types of non-glacial areas in the basin were divided into four categories: Bare rock, sparse vegetation, kobresia tibetica marsh meadow, and alpine kobresia meadow. The alpine kobresia meadow accounted for about $68 \%$ of the total area. The soil types were divided into: Alpine cold desert soil, alpine screes, cryo-sod soil, sand gravel accumulation body, stone cold orthent, the arid soil of the stone simple-bred cold, stone fiber frozen organic soil, and fiber frozen organic soil [15]. 


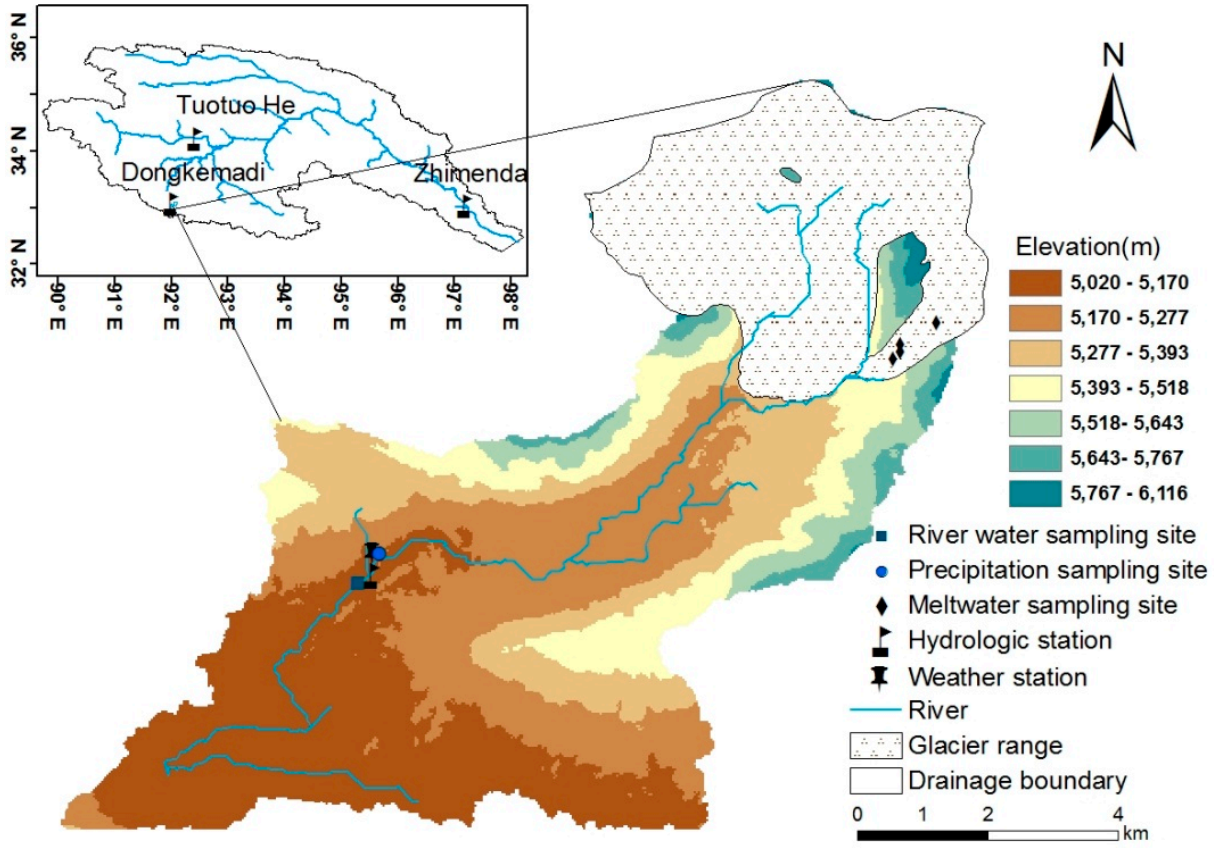

Figure 1. The location of the Dongkemadi River Basin and the distribution of the observation sites.

\subsection{Sampling and Analysis}

During the period June-October of 2014, 247 natural water samples were collected from the Dongkemadi basin (sample locations are shown in Figure 1): 148 were river water samples collected at 18:00 every day, 72 samples were atmospheric precipitation water, and 27 were samples of glacier meltwater collected on the glacier. Each sample was collected by plastic basins which were washed with ultrapure water, and pre-washed with precipitation immediately after each precipitation event stopped. All water samples were stored in the refrigerator immediately after collection. They were transported to the State Key Laboratory of Cryosphere Science, Northwest Institute of Eco-Environmental and Resources, Chinese Academy of Sciences, and cryopreserved at $-15{ }^{\circ} \mathrm{C}$. Samples were taken out two days before analysis in order to allow for natural melt. The $\mathrm{pH}$ and electrical conductivity (EC) were measured at room temperature. The $\delta^{18} \mathrm{O}$ and $\delta \mathrm{D}$ in the sample were measured by LDR-100 liquid water isotope analyzer from LGR (Los Gatos Research, San Jose, CA, USA). The cations $\left(\mathrm{Na}^{+}, \mathrm{K}^{+}, \mathrm{Mg}^{2+}, \mathrm{Ca}^{2+}\right)$ were treated using the Dionex-600 ion chromatography system. The anions $\left(\mathrm{Cl}^{-}, \mathrm{SO}_{4}{ }^{2-}, \mathrm{NO}_{3}{ }^{-}\right)$were determined by using the ICS-2500 ion chromatograph (Dionex Corporation, Sunnyvale, CA, USA). The cations had a measurement error of less than $0.1 \%$ and the anions of less than $0.3 \%$. The content of $\mathrm{HCO}_{3}{ }^{-}$was estimated by the ion balance relationship between anions and cations. The total dissolved solid (TDS) contents were calculated by subtracting half of $\mathrm{HCO}_{3}{ }^{-}$ from the sum of the ion contents. From the equilibrium relationship between dissolved $\mathrm{CO}_{3}{ }^{2-}$ and $\mathrm{HCO}_{3}{ }^{-}$in water, it is known that the content of $\mathrm{CO}_{3}{ }^{2-}$ is less than $5 \%$ of the sum of the two [16], so $\mathrm{CO}_{3}{ }^{2-}$ was negligible in this study.

\section{Results}

\subsection{Characteristics of Hydrochemical Compositions in Different Water Sources}

The chemical compositions of different waters in the Dongkemadi region are shown in Table 1. Due to the large number of samples, only the chemical eigenvalues $(\mathrm{mg} / \mathrm{L})$ of each water sample are listed in the table. The major hydrochemical composition type of the river water in the Dongkemadi region was $\mathrm{HCO}_{3}{ }^{-}-\mathrm{Ca}^{2+}$, and the concentration of the cations in the river, in order of decreasing concentration, were: $\mathrm{Ca}^{2+}>\mathrm{Mg}^{2+}>\mathrm{Na}^{+}>\mathrm{K}^{+}$, and the anions were $\mathrm{HCO}_{3}{ }^{-}>\mathrm{SO}_{4}{ }^{2-}>\mathrm{NO}_{3}{ }^{-}>\mathrm{Cl}^{-}$. The abundance of cations in the Dongkemadi River were different 
from that in the crust $\left(\mathrm{Ca}^{2+}>\mathrm{Na}^{+}>\mathrm{K}^{+}>\mathrm{Mg}^{2+}\right)$ and in the seawater $\left(\mathrm{Na}^{+}>\mathrm{Mg}^{2+}>\mathrm{Ca}^{2+}>\mathrm{K}^{+}\right)$. This shows that the river water ions in the Dongkemadi region not only simply reflect the impacts of terrestrial or marine sources, but also is related to the unique alpine mountain glacier environment to some extent.

The key difference between the precipitation and meltwater and the river water was the much lower concentration of cations and anions The hydrochemical type of the meltwater was in accordance with the river water $\left(\mathrm{HCO}_{3}{ }^{-}-\mathrm{Ca}^{2+}\right)$, reflecting that more than $70 \%$ of meltwater becomes runoff. The hydrochemical type of the precipitation was $\mathrm{HCO}_{3}{ }^{-}-\mathrm{SO}_{4}{ }^{2-}-\mathrm{Ca}^{2+}$, which was different from the other water bodies in the basin, but it is consistent with the precipitation of other headwater regions in the west, reflecting that more than $70 \%$ of $\mathrm{SO}_{4}{ }^{2-}$ in the precipitation is derived from Asian dust [17]. The order of the cation concentrations in the precipitation and meltwater was the same as that in the crust, which also reflects that precipitation and meltwater are controlled by the terrestrial materials. Whereas the order of the anion concentrations in the meltwater were ordered as following: $\mathrm{HCO}_{3}{ }^{-}>\mathrm{NO}_{3}{ }^{-}>\mathrm{SO}_{4}{ }^{2-}>\mathrm{Cl}^{-}$. 
Table 1. The hydrochemical characteristics of the runoff, precipitation, and meltwater in the Dongkemadi Basin.

\begin{tabular}{|c|c|c|c|c|c|c|c|c|c|c|c|}
\hline Water Sample & Eigen-Value & $\mathrm{Ca}^{2+}$ & $\mathrm{Mg}^{2+}$ & $\mathrm{Na}^{+}$ & $\mathbf{K}^{+}$ & $\mathrm{SO}_{4}^{2-}$ & $\mathrm{NO}_{3}{ }^{-}$ & $\mathrm{Cl}^{-}$ & $\mathrm{HCO}_{3}{ }^{-}$ & TDS & $\begin{array}{l}\text { Hydrochemical } \\
\text { Characteristics }\end{array}$ \\
\hline \multirow{3}{*}{ Runoff } & $\max$ & 51.36 & 16.14 & 18.16 & 2.13 & 18.32 & 260.08 & 15.27 & 237.11 & 238.76 & \multirow{3}{*}{$\mathrm{HCO}_{3}{ }^{-}-\mathrm{Ca}^{2+}$} \\
\hline & mid-value & 21.33 & 2.34 & 1.86 & 0.70 & 3.07 & 0.42 & 0.44 & 81.30 & 73.61 & \\
\hline & $\min$ & 0.37 & 0.03 & 0.15 & nd & 0.06 & 0.02 & 0.03 & 1.93 & 1.97 & \\
\hline \multirow{3}{*}{ Precipitation } & $\max$ & 43.34 & 8.38 & 27.24 & 1.95 & 37.60 & 5.72 & 1.13 & 168.15 & 143 & \multirow{3}{*}{$\mathrm{HCO}_{3}{ }^{-}-\mathrm{SO}_{4}{ }^{2-}-\mathrm{Ca}^{2+}$} \\
\hline & mid-value & 0.80 & 0.04 & 0.53 & 0.10 & 0.37 & 0.34 & 0.07 & 4.55 & 7.54 & \\
\hline & $\min$ & 0.17 & 0.01 & 0.03 & 0.01 & 0.01 & 0.02 & 0.01 & 0.69 & 2.16 & \\
\hline \multirow{3}{*}{ Meltwater } & $\max$ & 5.42 & 0.54 & 2.14 & 4.36 & 0.31 & nd & 1.06 & 17.76 & 18.74 & \multirow{3}{*}{$\mathrm{HCO}_{3}{ }^{-}-\mathrm{Ca}^{2+}$} \\
\hline & mid-value & 0.48 & 0.07 & 0.16 & 0.07 & 0.05 & 0.08 & 0.03 & 2.65 & 4.87 & \\
\hline & $\min$ & 0.21 & 0.01 & 0.05 & 0.01 & 0.01 & 0.33 & 0.01 & 1.06 & 1.54 & \\
\hline
\end{tabular}

Note: nd indicates that the concentration was not detected and was lower than the instrument detection value. 


\subsection{Relationship between Hydrochemical Compositions and the Runoff in the River}

The TDS content is a comprehensive indicator of the ion concentration in water. Generally, the greater the dissolved load, the larger the TDS value. As shown in Table 1, the TDS concentrations were ordered: River water $>$ precipitation $>$ meltwater. The median TDS value in the runoff was $73.61 \mathrm{mg} / \mathrm{L}$, which was much larger than that in the precipitation $(7.54 \mathrm{mg} / \mathrm{L})$ and meltwater $(4.87 \mathrm{mg} / \mathrm{L})$. The variation of TDS with runoff, precipitation, and temperature during the glacier ablation period in the Dongkemadi basin is shown in Figure 2. From June to mid-August, with the increase of precipitation recharge, the TDS in the runoff showed a decreasing trend due to the dilution effect of precipitation with a low ion concentration. The analysis showed that the temperature had a significant positive correlation with the runoff. The glacial meltwater contribution increased because of the temperature rising, and the dilution effect of the glacial meltwater on the runoff solutes was enhanced [18], which was one of the reasons for the TDS decrease in the runoff. At the same time, there are studies that have shown that the variation of ion concentrations in the runoff is related to the flow rate [19]. The vertical height fluctuation is large in headwater regions; as the runoff increases, the flow rate increases, the touch time between the water body and the river bed is relatively short, and the amount of soluble salt in the rock soil dissolved in water is relatively small. On the contrary, the temperature and precipitation decreased after September, and the recharge of low-concentration water to the river runoff decreased. With the runoff in the Dongkemadi basin decreasing continuously, the dilution reduced and the contact time with the sediments increased, thus the concentration of TDS in the river water increased relatively.

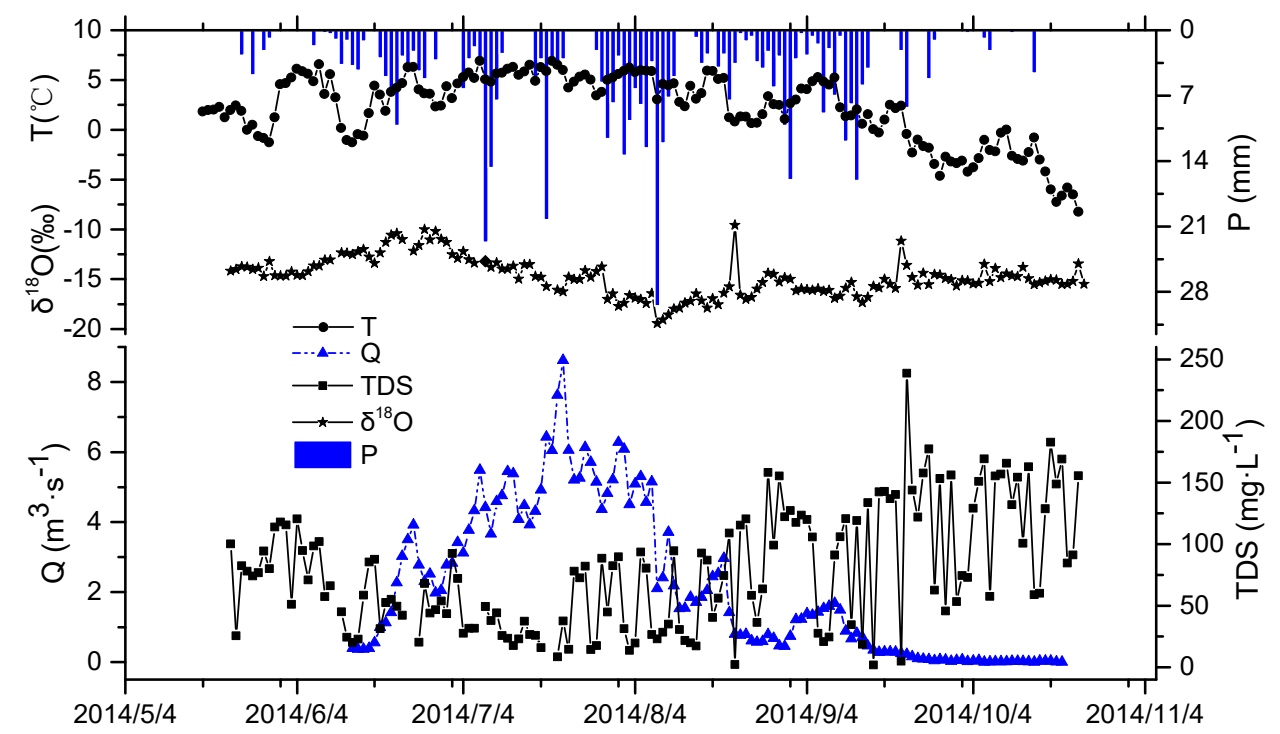

Figure 2. Daily values of the TDS, $\delta^{18} \mathrm{O}$ values, precipitation $(\mathrm{P})$, temperature $(\mathrm{T})$, and discharge $(\mathrm{Q})$ in the summer season (glacier ablation period) of 2014 in the Dongkemadi River Basin.

It can be seen from Figure 3 that the ion concentrations in the river water were opposite to the runoff change in summer. The ion concentration decreased with the increase in runoff, which is mainly affected by the eluviation effect of runoff ions. Some studies have shown that there exists a power function relationship $\left(C=a \times Q^{b}\right)$ between runoff and the concentration of the dissolved load in the river water in most rivers $[20,21]$. $C$ is the ion concentration, $Q$ is the daily average runoff, and a and $\mathrm{b}$ are the fitting parameters. The $\mathrm{b}$ reflects the relationship between ion concentration and runoff, $b=-1$ indicates that the ion characteristics of the river change completely with the variation of runoff, and $b=0$ indicates the variation of ions in the river completely under the control of runoff. In Figure 3, the $b$ value of the major ions in the river water, except for $\mathrm{Mg}^{2+}, \mathrm{Na}^{+}$, and $\mathrm{SO}_{4}{ }^{2-}$, was smaller than the global average value $(-0.17)$, and the $\mathrm{Cl}^{-}$ion concentration was not significantly affected by the runoff. Although the $b$ value of $\mathrm{Cl}^{-}$was -0.2 with $\mathrm{R}^{2}=0.06$. This indicates that there was little relationship 
between the two, and it means that the ion concentrations of $\mathrm{Cl}^{-}$were completely independent to the change of runoff. This further verifies that the tracer was stable in the water cycle.
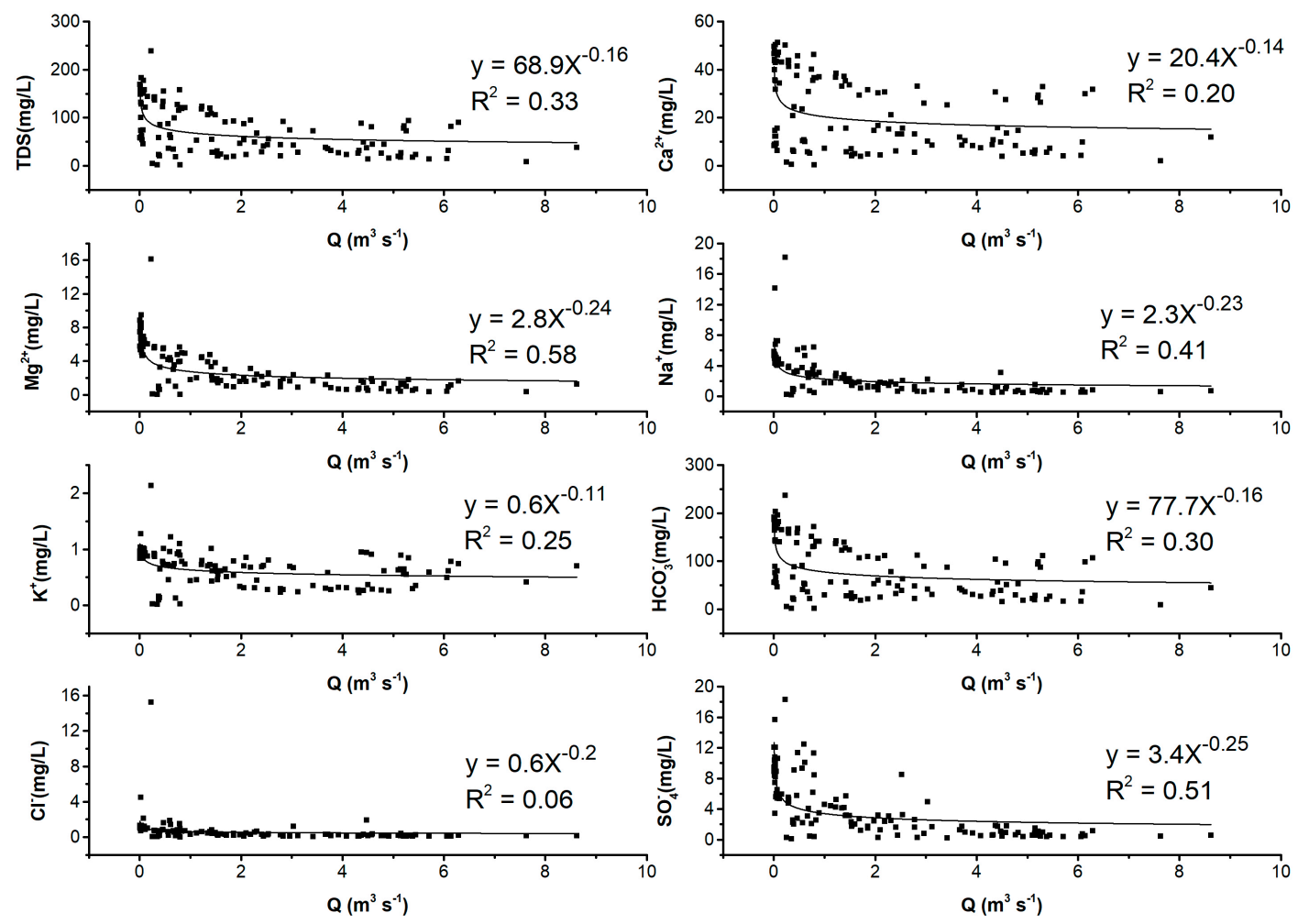

Figure 3. The relationship between major ions and discharge in summer in the Dongkemadi River.

\section{Discussion}

\subsection{Sources of Major Ions in River Water and Its Controlling Factors}

The migration and transformation of hydrochemical ions in river water are mainly controlled by geological and climatic factors. The weathering of rock determines the chemical compositions of the major ions in a river. The climatic factors, especially the temperature and precipitation, have a large impact on the concentrations of ions in the glacial area of the alpine region. In addition, human activities have an impact on hydrochemical changes, which are negligible in this paper. Generally, sources of chemical compositions in a watershed can be qualitatively analyzed by using Gibbs semi-logarithmic coordinates [22]. Low contents of $\mathrm{Cl}^{-}$and $\mathrm{Na}^{+}$and higher contents of $\mathrm{HCO}_{3}{ }^{-}$and $\mathrm{Ca}^{2+}$ reflect that the river water is influenced by the rock in that river basin $[23,24]$. As shown in Figure 4 , the ratios of $\mathrm{Na}^{+} /\left(\mathrm{Na}^{+}+\mathrm{Ca}^{2+}\right)$ and $\mathrm{Cl}^{-} /\left(\mathrm{Cl}^{-}+\mathrm{HCO}_{3}{ }^{-}\right)$in the Dongkemadi River are less than 0.5 , and the sample distribution of the river water is on the left side of the middle of the figure. That is different from that of the meltwater distribution, indicating that the ion compositions of runoff are not completely derived from the meltwater, and are mainly controlled by the rock weathering in the basin. The conclusion is similar to the results of studies in other basins of the Tibetan Plateau, which also confirm the important role of the weathering of rock on the ion compositions of river runoffs $[13,20]$. 

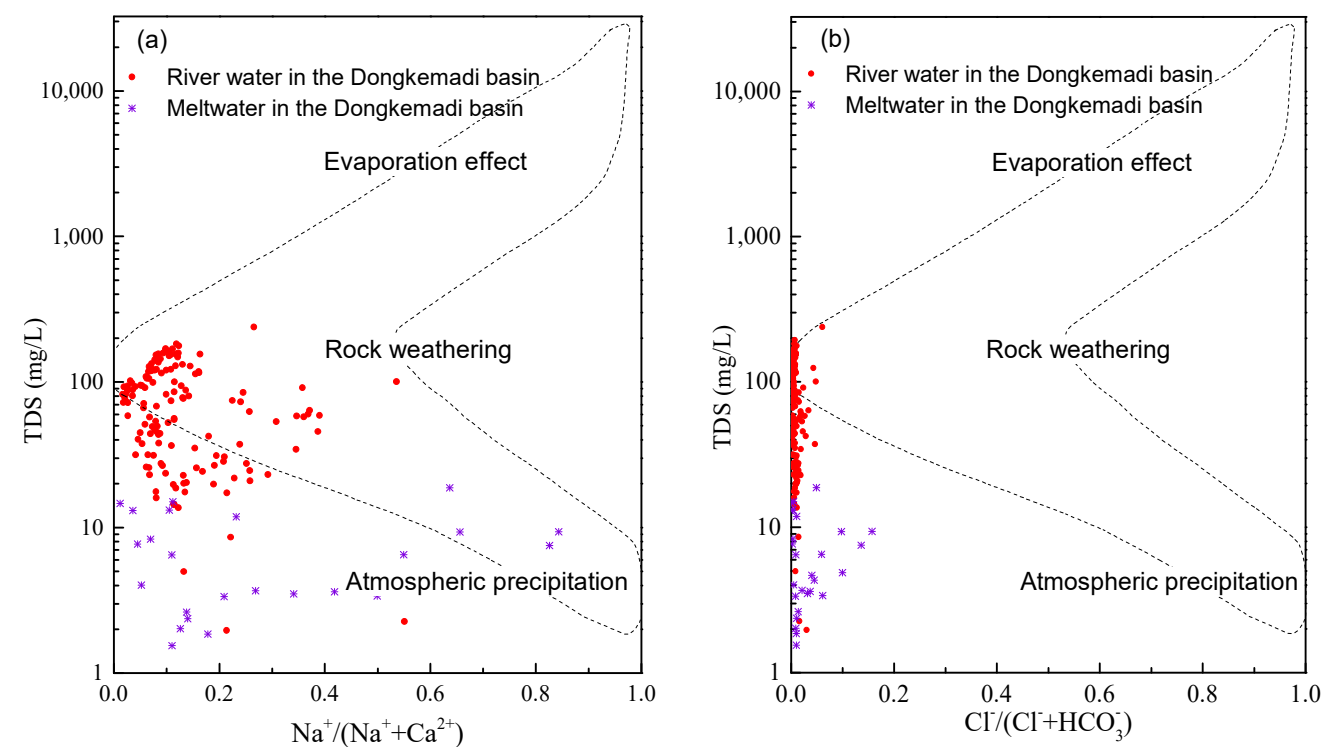

Figure 4. Gibbs diagram of the runoff of the Dongkemadi River. (a) the changes of the TDS and the ratios of $\mathrm{Na}^{+} /\left(\mathrm{Na}^{+}+\mathrm{Ca}^{2+}\right)$ in river water and meltwater; $(\mathbf{b})$ the changes of the TDS and the ratios of $\mathrm{Cl}^{-} /\left(\mathrm{Cl}^{-}+\mathrm{HCO}_{3}^{-}\right)$.

The ratio of $\left(\mathrm{Mg}^{2+}+\mathrm{Ca}^{2+}\right) /\left(\mathrm{Na}^{+}+\mathrm{K}^{+}\right)$in river water is always used to assess the effect of different minerals on the hydrochemistry [25]. As shown in Figure 5b, the concentration of $\left(\mathrm{Mg}^{2+}+\mathrm{Ca}^{2+}\right)$ in the river water of the Dongkemadi River Basin is obviously larger than that of $\left(\mathrm{Na}^{+}+\mathrm{K}^{+}\right)$, indicating that $\mathrm{Mg}^{2+}$ and $\mathrm{Ca}^{2+}$ may be derived from the dissolution of evaporites and dolomites. While Figure $5 \mathrm{a}$ shows that $\left(\mathrm{Mg}^{2+}+\mathrm{Ca}^{2+}\right)$ and $\mathrm{HCO}_{3}{ }^{-}$are significantly correlated $\left(\mathrm{R}^{2}=0.99\right)$, it indicates that $\mathrm{Mg}^{2+}$ and $\mathrm{Ca}^{2+}$ in the runoff may be derived from the dissolution of carbonate minerals. The relationship between $\left(\mathrm{Mg}^{2+}+\mathrm{Ca}^{2+}\right)$ and half of $\left(\mathrm{HCO}_{3}{ }^{-}+\mathrm{SO}_{4}{ }^{2-}\right)$ also have very good consistency (Figure $5 \mathrm{c}$ ), and the linear fit is close to 1:1, indicating the important effect of the dissolution of carbonate minerals and sulfate minerals on the runoff ion composition in the the Dongkemadi River Basin [26,27]. The ratios of $\mathrm{Mg}^{2+} / \mathrm{Ca}^{2+}$ and $\mathrm{Na}^{+} / \mathrm{Ca}^{2+}$ in the water are always used to determine the dissolution of carbonate minerals in water [28]. The river water in the Dongkemadi River Basin has higher $\mathrm{Mg}^{2+} / \mathrm{Ca}^{2+}$ values and lower $\mathrm{Na}^{+} / \mathrm{Ca}^{2+}$ values, and $75 \%$ of the water samples are distributed above the 1:1 isocontour (Figure $5 \mathrm{~d}$ ), indicating that the carbonate minerals at the surface runoff are dominated by the dissolution of dolomites into the Dongkemadi River Basin. The hydrochemistry of the runoff in the Dongkemadi basin is derived from carbonate minerals of dolomite dissolution, evaporites dominated by rock salt and gypsum, and some minerals of silicate and sulfate.

The propulsion model was used to calculate the end member ratios of $\mathrm{Ca} / \mathrm{Na}$ and $\mathrm{Mg} / \mathrm{Na}$ in the basin in order to calculate the contributions of carbonate, silicate, and evaporate [29]. Gaillardet et al. [30] considered that the carbonate end member ratio of $\mathrm{Ca} / \mathrm{Na}$ is close to $50, \mathrm{Mg} / \mathrm{Na}$ is close to 120 , and the end member ratio of silicate is $\mathrm{Ca} / \mathrm{Na}=0.35 \pm 0.15$ and $\mathrm{Mg} / \mathrm{Na}=0.24 \pm 0.12$, according to multiple rivers. From Figure 6, the index of the Dongkemadi River is concentrated in the areas near carbonates and silicates. It means that the runoff hydrochemistry of the Dongkemadi river Basin is derived from carbonate minerals, which is mainly composed of the dissolution of dolomites, as well as some silicate minerals and evaporites, which are mainly composed of rock salts and gypsums. The contribution of evaporite rocks to the runoff hydrochemistry in the Dongkemadi River Basin is smaller, in comparison to the other two types, according to the distance distribution in Figure 6. 

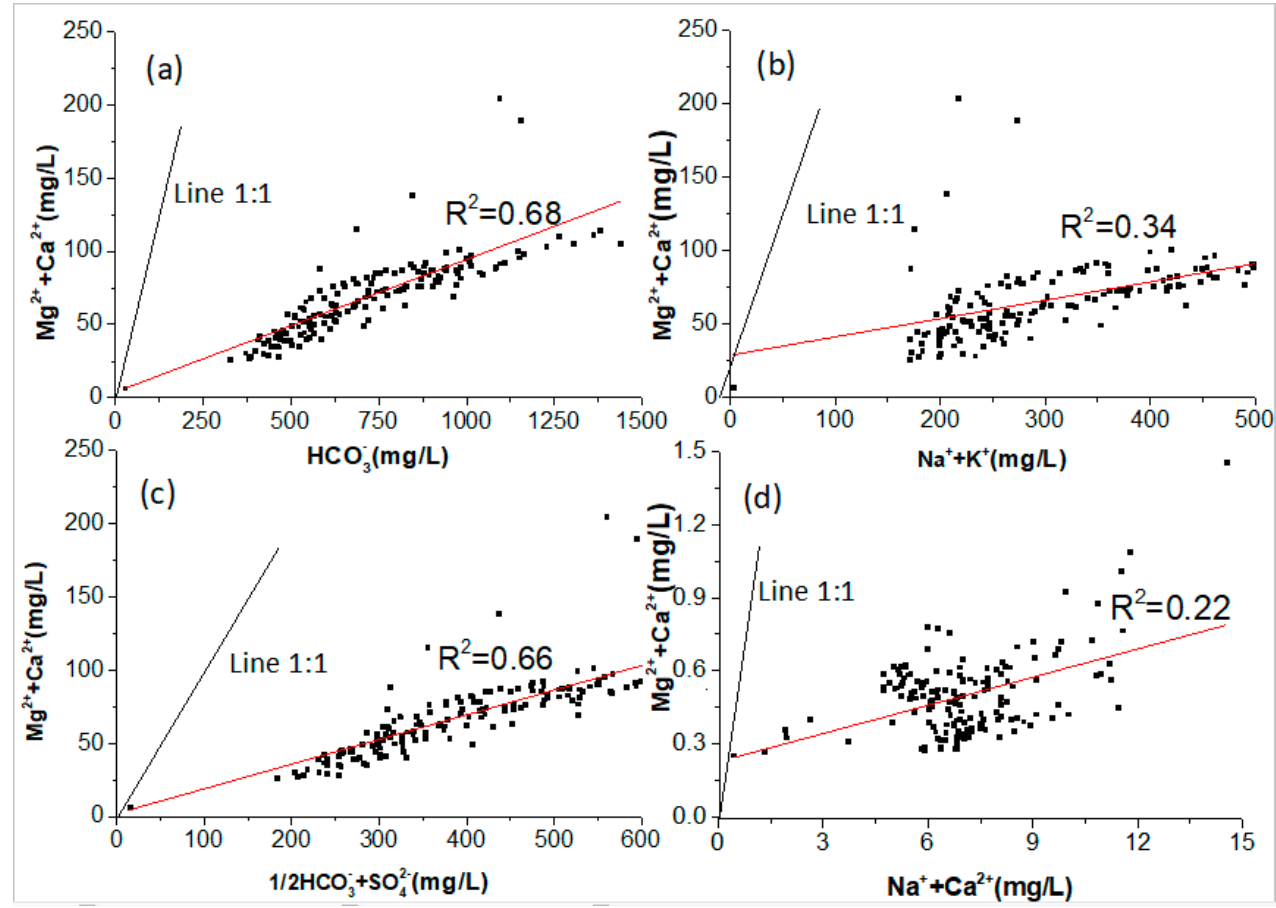

(d)

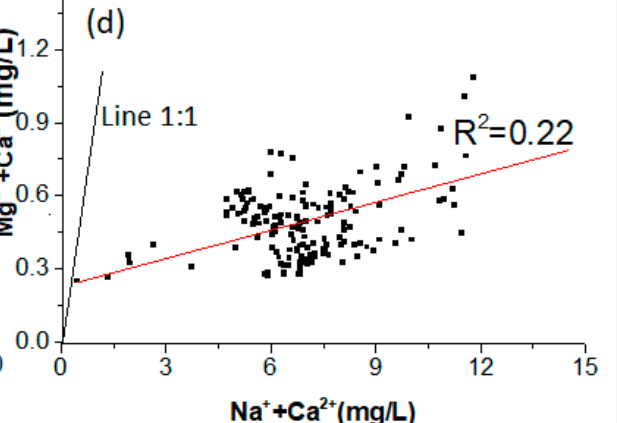

Figure 5. Proportions of the major ions in the runoff of the Dongkemadi River. (a) the relationship between the $\left(\mathrm{Mg}^{2+} / \mathrm{Ca}^{2+}\right)$ and $\mathrm{HCO}_{3}{ }^{-} ;(\mathbf{b})$ the relationship between the $\left(\mathrm{Mg}^{2+} / \mathrm{Ca}^{2+}\right)$ and $\left(\mathrm{Na}^{+} / \mathrm{K}^{+}\right)$; (c) the relationship between the $\left(\mathrm{Mg}^{2+} / \mathrm{Ca}^{2+}\right)$ and $\left(1 / 2 \mathrm{HCO}_{3}{ }^{-}+\mathrm{SO}_{4}{ }^{2-}\right)$; (d) the relationship between the $\left(\mathrm{Na}^{+} / \mathrm{Ca}^{2+}\right)$ and $\left(\mathrm{Mg}^{2+} / \mathrm{Ca}^{2+}\right)$.

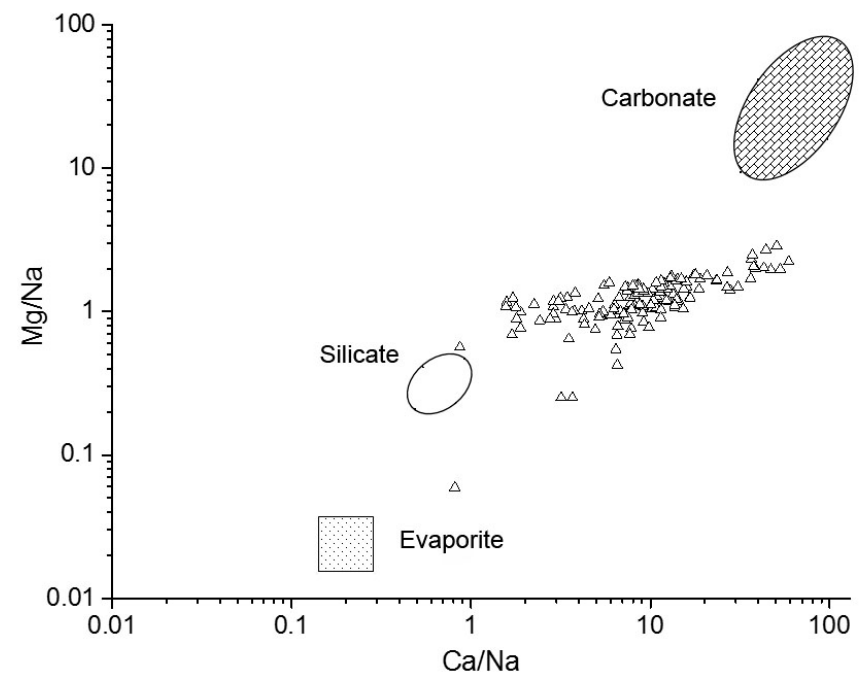

Figure 6. Molar ratios of $\mathrm{Mg} / \mathrm{Na}$ and $\mathrm{Ca} / \mathrm{Na}$, not corrected for atmospheric input. End member compositions for carbonate, silicate, and evaporite are slightly modified from Gaillardet.

\subsection{Contributions of Different Sources to Dissolved Composition in River Water}

The source of the dissolved load in river water mainly includes atmospheric sedimentation, mineral dissolution, and human input. The minerals include carbonates, silicates, evaporites, and sulfides. The mass balance equation of ions in water is as follow [26]:

$$
(X)_{\text {river }}=(X)_{\text {rain }}+(X)_{\text {carb }}+(X)_{\text {sil }}+(X)_{\text {eva }}
$$


where $\mathrm{X}$ is any chemical ions in river water; river means river water; rain represents atmospheric precipitation; carb is carbonate mineral; sil is silicate mineral; and Eva is evaporite mineral. The forward modeling approach [31,32] was used to quantify the contribution rate of each end member to the Dongkemadi River runoff.

\subsubsection{Contribution of Precipitation to the Hydrochemistry in the Dongkemadi River}

The main inputs from the atmosphere that are dissolved in river water are sea salt and atmospheric dust [31]. The $\mathrm{Cl}^{-}$in atmospheric precipitation is mainly from sea salt ions and are relatively stable in the water cycle, thus it is always used to study the contribution of atmospheric transport to surface hydrochemistry [28,33]. In addition, the summer monsoon moisture also should be considered, because the low $\mathrm{D}$ excess and low $\delta^{18} \mathrm{O}$ of precipitation on the southern Tibetan Plateau is influenced by the monsoon in summer [34]. There are many methods for correcting atmospheric precipitation ions [22,29,35]. In this paper, the contribution rate of atmospheric precipitation to the dissolved load of runoff was estimated according to the minimum value of $\mathrm{Cl}^{-}$in the runoff (mainly from atmospheric precipitation), and the ratios of ion concentrations in the precipitation. After calibration, the ion content of the precipitation $\left((X)_{\text {rain }}\right)$ was calculated by the following formula:

$$
(\mathrm{X})_{\text {rain }}=\left(\mathrm{X} / \mathrm{Cl}^{-}\right)_{\text {rain }} \times \mathrm{Cl}^{-} \text {ref }
$$

where $\left(\mathrm{X} / \mathrm{Cl}^{-}\right)_{\text {rain }}$ is the ratio of major cations and $\mathrm{Cl}^{-}$in the precipitation; $\mathrm{Cl}^{-}$ref is the maximum transport concentration of $\mathrm{Cl}^{-}$from precipitation to runoff, in other words, it means the minimum $\mathrm{Cl}^{-}$in river water. The value of $\mathrm{Cl}^{-}$ref is $0.88 \mu \mathrm{mol} / \mathrm{L}$, which is the minimum $\mathrm{Cl}^{-}$in the Dongkemadi River Basin. After calibration, the cation concentration is $\sum$ cation $_{\text {rain }}=21.6 \mu \mathrm{mol} / \mathrm{L}$ in the precipitation, nevertheless, the cation concentration is $\sum$ cation $_{\text {river }}=729.4 \mu \mathrm{mol} / \mathrm{L}$ in the river water. Therefore, the cation of precipitation contributes about $3 \%$ of the hydrochemical cations in the river water in the Dongkemadi River Basin.

\subsubsection{Contributions of the Dissolution of Minerals to River Hydrochemistry}

In addition to the contribution rate of precipitation ions, the ion compositions of river water are mainly dissolved by evaporites (rock salt and gypsum), silicates, and carbonates. Except for precipitation, $\mathrm{Cl}^{-}$and $\mathrm{SO}_{4}{ }^{2-}$ in rivers mainly come from the dissolution of evaporites; $\mathrm{Na}^{+}$is derived from the dissolution of evaporites and silicates; $\mathrm{K}^{+}$is derived from the dissolution of silicates; $\mathrm{SO}_{4}{ }^{2-}$ and $\mathrm{Ca}^{2+}$ are produced by the dissolution of evaporates, and are in equilibrium with $\mathrm{Mg}^{2+}$. When rock salt dissolves in water, it releases the same amount of $\mathrm{Na}^{+}$and $\mathrm{Cl}^{-} \cdot \mathrm{Ca}^{2+}$ and $\mathrm{Mg}^{2+}$ are present in various minerals [32,36]. The contributions of $\mathrm{Ca}^{2+}$ and $\mathrm{Mg}^{2+}$ of mineral solutes to the composition of river water ions can be calculated by the following formulas:

$$
\begin{gathered}
\left(\mathrm{Ca}^{2+}\right)_{\text {river }}=\left(\mathrm{Ca}^{2+}\right)_{\text {rain }}+\left(\mathrm{Ca}^{2+}\right)_{\text {eva }}+\left(\mathrm{Ca}^{2+}\right)_{\text {sil }}+\left(\mathrm{Ca}^{2+}\right)_{\text {carb }} \\
\left(\mathrm{Mg}^{2+}\right)_{\text {river }}=\left(\mathrm{Mg}^{2+}\right)_{\text {rain }}+\left(\mathrm{Mg}^{2+}\right)_{\text {sil }}+\left(\mathrm{Mg}^{2+}\right)_{\text {carb }}+\left(\mathrm{Mg}^{2+}\right)_{\text {eva }}
\end{gathered}
$$

The contribution rate of rock salt to the dissolved load of river water $\left(\mathrm{Cl}^{-}\right)_{\mathrm{eva}} / \sum$ cation river $)$ is $1.6 \%$, and the contribution rate of gypsum to the ion composition of river water $\left(\left(\mathrm{Ca}^{2+}\right)_{\text {eva }} / \sum\right.$ cation $\left._{\text {river }}\right)$ is $4.1 \%$. The sum of the above two rates, which is $5.7 \%$, is the contribution rate of the weathering of evaporite minerals to the hydrochemical cations of river water in the Dongkemadi River Basin. The contents of $\left(\mathrm{Ca}^{2+}\right)_{\text {sil }}$ and $\left(\mathrm{Mg}^{2+}\right)_{\text {sil }}$, which are released by silicates, can be estimated by $\left(\mathrm{Na}^{+}\right)_{\text {sil }}$ in its dissolution process, namely: $\quad\left(\mathrm{Ca}^{2+}\right)_{\text {sil }}=\left(\mathrm{Na}^{+}\right)_{\text {sil }} \times\left(\mathrm{Ca}^{2+} / \mathrm{Na}^{+}\right)_{\text {sil }},\left(\mathrm{Mg}^{2+}\right)_{\text {sil }}=\left(\mathrm{Na}^{+}\right)_{\text {sil }} \times\left(\mathrm{Mg}^{2+} / \mathrm{Na}^{+}\right)_{\text {sil }}$. However, due to the unknown understanding of the bedrock compositions of the Dongkemadi River Basin, especially as the ratio of $\mathrm{Ca}^{2+}, \mathrm{Mg}^{2+}$, and $\mathrm{Na}^{+}$in the silicates are unknown, the ratio of silicate mineral concentrations in the global average crust 
is taken [32]: $\left[\mathrm{Ca}^{2+} / \mathrm{Na}^{+}\right]_{\mathrm{sil}}=0.35,\left(\mathrm{Mg}^{2+} / \mathrm{Na}^{+}\right)_{\mathrm{sil}}=0.24 ;$ the cation concentration in the silicates is calculated by $\sum$ cation ${ }_{\text {sil }}=\left(\mathrm{Ca}^{2+}\right)_{\mathrm{sil}}+\left(\mathrm{Mg}^{2+}\right)_{\mathrm{sil}}+\left(\mathrm{Na}^{+}\right)_{\mathrm{sil}}+\left(\mathrm{K}^{+}\right)_{\mathrm{sil}}=113 \mu \mathrm{mol} / \mathrm{L}$. Therefore, the contribution of silicate mineral weathering to the hydrochemical cations is $15.5 \%$ in the Dongkemadi River. It can be known from formula (1) that the contribution rate of carbonate mineral weathering to runoff hydrochemical cations is $75.8 \%$.

\subsection{Rate of Rock Weathering and $\mathrm{CO}_{2}$ Consumption Fluxes in The Drainage Basin}

Based on the chemical weathering of each ion in river water, the amount of weathering erosion and $\mathrm{CO}_{2}$ consumption flux in the Dongkemadi River Basin can be evaluated. The chemical weathering rate of silicates (SWR) and the chemical weathering erosion rate of carbonates (CWR) can be expressed as $[28,29,31]$ :

$$
\begin{gathered}
\left.\mathrm{SWR}=\left(\mathrm{Ca}^{2+}{ }_{\text {sil }}+\left(\mathrm{Mg}^{2+}\right)_{\text {sil }}+\left(\mathrm{Na}^{+}\right)_{\text {sil }}+\left(\mathrm{K}^{+}\right)_{\text {sil }}\right)\right) \times \mathrm{Q} / \mathrm{A} \\
\left.\mathrm{CWR}=\left(\left(\mathrm{Ca}^{2+}\right)_{\mathrm{carb}}+\left(\mathrm{Mg}^{2+}\right)_{\mathrm{carb}}+0.5 \times\left(\mathrm{HCO}_{3}{ }^{-}\right)_{\mathrm{carb}}\right)\right) \times \mathrm{Q} / \mathrm{A} \\
\left.\Phi \mathrm{CO}_{2}{ }^{-}{ }_{\text {sil }}=\left(\left(2 \times\left(\mathrm{Ca}^{2+}\right)_{\text {sil }}+\left(\mathrm{Mg}^{2+}\right)_{\text {sil }}\right)+\left(\mathrm{Na}^{+}\right)_{\text {sil }}+\left(\mathrm{K}^{+}\right)_{\text {sil }}\right)\right) \times \mathrm{Q} / \mathrm{A} \\
\left.\Phi \mathrm{CO}_{2}{ }^{-}{ }_{\text {carb }}=\left(\left(\mathrm{Ca}^{2+}\right)_{\mathrm{carb}}+\left(\mathrm{Mg}^{2+}\right)_{\mathrm{carb}}\right)\right) \times 2 \times \mathrm{Q} / \mathrm{A}
\end{gathered}
$$

Among them, $\mathrm{Q}$ is the annual runoff $\left(\mathrm{m}^{3} \cdot \mathrm{a}^{-1}\right)$ of the base section in the Dongkemadi River Basin; $A$ is the basin area $\left(\mathrm{km}^{2}\right)$. During the weathering process of carbonate minerals, half of the concentration of $\mathrm{HCO}_{3}{ }^{-}$is derived from the atmosphere, and the contribution rate of the atmospheric precipitation to the river water cations is small in the Dongkemadi River Basin, so it is neglected in estimating the weathering erosion rate of carbonates. Therefore, the weathering rate of silicate minerals is $1.98 \mathrm{t} \cdot \mathrm{km}^{-2} \cdot \mathrm{a}^{-1}$ by calculation, and carbonate minerals are $12.30 \mathrm{t} \cdot \mathrm{km}^{-2} \cdot \mathrm{a}^{-1}$. In the Dongkemadi River Basin, the chemical weathering of silicates and carbonate minerals to $\mathrm{CO}_{2}$ consumption rate is $0.91 \times 10^{5} \mathrm{~mol} \cdot \mathrm{km}^{-2} \cdot \mathrm{a}^{-1}$ and $3.28 \times 10^{5} \mathrm{~mol} \cdot \mathrm{km}^{-2} \cdot \mathrm{a}^{-1}$, respectively.

It can be seen from Table 2 that the ion fluxes in the glacial basin are significantly higher than those in the non-glacier area of the alpine mountain. In the Dongkemadi River Basin, the $\mathrm{CO}_{2}$ consumption fluxes from the chemical reactions of $\mathrm{CO}_{2}$ and the silicate minerals from hydrochemical weathering are significantly higher than that in other rivers of the Yangtze River source area, such as the Tuotuohe River, Jinsha River, and the upper reaches of the Yellow River. It shows that the chemical weathering rates of rivers and the $\mathrm{CO}_{2}$ consumption fluxes in the glacial action area are much larger than those in non-glaciers, in other words, it has a certain inhibitory effect on global warming. 
Table 2. Chemical weathering and $\mathrm{CO}_{2}$ consumption rate in the Dongkemadi River region.

\begin{tabular}{|c|c|c|c|c|c|c|c|c|}
\hline Drainage Basin & $\begin{array}{c}\text { Runoff } \\
\left(10^{8} \mathrm{~m}^{3} \mathrm{a}^{-1}\right)\end{array}$ & $\begin{array}{l}\text { Drainage Area } \\
\left(10^{3} \mathrm{~km}^{2}\right)\end{array}$ & 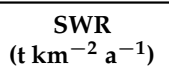 & 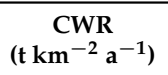 & $\begin{array}{c}\mathrm{TDS}_{\text {total }} \\
\left(\mathrm{t} \mathrm{km}^{-2} \mathbf{a}^{-1}\right)\end{array}$ & $\begin{array}{c}\Phi \mathrm{CO}_{2}{ }^{-} \mathrm{sil} \\
\left(10^{5} \mathrm{~mol} \mathrm{~km}^{-2} \mathrm{a}^{-1}\right)\end{array}$ & $\begin{array}{c}\Phi \mathrm{CO}_{2}^{-}{ }^{-} \text {carb } \\
\left(10^{5} \mathrm{~mol} \mathrm{~km}^{-2} \mathrm{a}^{-1}\right)\end{array}$ & Source \\
\hline Dongkemadi & 0.24 & 0.039 & 1.98 & 12.30 & 14.82 & 0.91 & 3.28 & This study \\
\hline Tuotuohe & 13.37 & 15.92 & 1.19 & 1.61 & 2.80 & 0.46 & 1.35 & [37] \\
\hline Jinsha Jiang & 394 & 229 & 1.39 & 16.93 & 18.32 & 0.34 & 1.40 & [37] \\
\hline Upstream Yellow River & 380 & 223 & 2.33 & 27.4 & 29.73 & 0.14 & 3.04 & [38] \\
\hline Glacier No.1 & 0.02 & 0.003 & - & - & 18.1 & - & - & [39] \\
\hline Haut Glacier & - & 0.012 & - & - & 13.7 & - & - & [40] \\
\hline
\end{tabular}




\section{Conclusions}

In the Dongkemadi River Basin, the hydrochemical type of the river water is $\mathrm{HCO}_{3}{ }^{-} \mathrm{Ca}^{2+}$. The major cations are $\mathrm{Ca}^{2+}$ and $\mathrm{Mg}^{2+}$, and the major anions are $\mathrm{HCO}_{3}{ }^{-}$and $\mathrm{SO}_{4}{ }^{2-}$ The major ions concentrations and the TDS of the river water are much larger than those of the precipitation and the meltwater. The TDS concentration is ordered: River water $>$ precipitation $>$ meltwater.

The concentration change of the river water ions is inversely related to runoff. The ratios of $\mathrm{Na}^{+} /\left(\mathrm{Na}^{+}+\mathrm{Ca}^{2+}\right)$ and $\mathrm{Cl}^{-} /\left(\mathrm{Cl}^{-}+\mathrm{HCO}_{3}{ }^{-}\right)$in the Dongkemadi River are less than 0.5 , which is different from that of the meltwater distribution, indicating that the ion compositions of the runoff are not completely derived from the meltwater, and are mainly controlled by the weathering of rock in the basin. With the glacier retreat and glacier meltwater declining, the ratios of $\mathrm{Na}+/\left(\mathrm{Na}^{+}+\mathrm{Ca}^{2+}\right)$ and $\mathrm{Cl}^{-} /\left(\mathrm{Cl}^{-}+\mathrm{HCO}_{3}{ }^{-}\right)$in the Dongkemadi River will decrease correspondingly.

The chemical compositions of the river water ions are mainly affected by the weathering of rock. According to the forward modelling approach, the contributions of different sources to the dissolved components of the Dongkemadi River are ordered: Carbonate > silicate $>$ evaporite $>$ atmospheric precipitation.

Author Contributions: Conceptualization, T.H., X.L. and J.Q.; methodology, T.H. and Y.L.; software, Y.L.; validation, Y.L.; formal analysis, J.Q.; investigation, Y.L.; resources, T.H. and X.L.; data curation, T.H., Q.Y. and X.H; writing—original draft preparation, T.H. and Y.L.; writing—review and editing, Y.L., J.Q. and Q.Y.; visualization, J.Q.; supervision, J.Q.; project administration, J.Q.; funding acquisition, T.H., X.L. and J.Q.

Funding: This research was funded by the National Natural Science Foundation of China, grant numbers 41771040, 41730751, 91647102, and 41877156. And the International Science \&Technology Cooperation Program of China, grant number 2018YFE0100100.

Acknowledgments: The authors are grateful to $\mathrm{R}$. Xu for her contribution to water sample analysis which allows this study to progress in good conditions.

Conflicts of Interest: The authors declare no conflict of interest.

\section{References}

1. IPCC. Summery for Policymaker. In Climate Change 2013: The Physical Science Basis. Contribution of Working Group I to the Fifth Assessment Report of the Intergovernmental Panel on Climate Change; Stocker, T.F., Qin, D., Plattner, G.K., Eds.; Cambridge University Press: Cambridge, UK, 2013; pp. 3-29.

2. Ren, G.Y.; Chu, Z.Y.; Zhou, Y.Q. Recent progresses in studies of regional temperature changes in China. Clim. Environ. Res. 2005, 10, 701-716.

3. Dou, R.Y. The climate change and adaptation strategies for sustainable development in the Three-River headwaters region in Qinghai province in recent half century. Ecol. Econ. (Chinese version) 2016, 32, 165-171.

4. Shen, Y.P.; Liu, S.Y.; Ding, Y.J. Glacier mass balance change in Tailanhe River Watersheds on the south slope of the Tianshan Mountains and its impact on water resources. J. Glaciol. Geocryol. 2003, 25, 124-129.

5. Li, Z.X.; He, Y.Q.; Jia, W.X. Response of "glaciers-runoff" system in a typical temperate-glacier, Hailuogou Glacier in Gongga Mountain of China to global change. Sci. Geogr. Sin. 2008, 28, 229-234.

6. Brown, G.H. Glacier meltwater hydrochemistry. Appl. Geochem. 2002, 17, 855-883. [CrossRef]

7. Liu, S.Y.; Ding, Y.J.; Li, J. Glaciers in response to recent climate warming in western China. Quat. Sci. 2006, 26, 762-771.

8. Pu, J.C.; Yao, T.D.; Yang, M.X. Rapid decrease of mass balance observed in the Xiao (Lesser) Dongkemadi Glacier, in the central Tibetan Plateau. Hydrol. Process. 2008, 22, 2953-2958. [CrossRef]

9. Ke, L.; Ding, X.; Li, W.; Qiu, B. Remote sensing of glacier change in the central Qinghai-Tibet Plateau and the relationship with changing climate. Remote Sens. 2017, 9, 114. [CrossRef]

10. Singh, A.K.; Hasnain, S.I. Aspects of weathering and solute acquisition processes controlling chemistry of sub-Alpine proglacial streams of Garhwal Himalaya, India. Hydrol. Process. 2002, 16, 835-849. [CrossRef]

11. Zhang, J.; He, X.B.; Ye, B.S. Rencent Variation of mass balance of the Xiao Dongkemadi Glacier in the Tanggula Range and its influencing factors. J. Glaciol. Geocryol. 2013, 35, 263-271.

12. Zhang, Y.S.; Yao, T.D.; Pu, J.C. The features of hydrological processing in the Dongkemadi River basin, Tanggula Pass, Tibetan Plateau. J. Glaciol. Geocryol. 1997, 19, 214-222. 
13. Liu, J.F.; Yang, J.P.; Chen, R.S. The simulation of snowmelt runoff model in the Dongkemadi River Basin, headwater of the Yangtze River. Acta Geogr. Sin. 2006, 61, 1149-1159.

14. Qiao, C.J.; He, X.B.; Ye, B.S. Study of the degree-day factors for snow and ice on the Dongkemadi Glacier, Tanggula Range. J. Glaciol. Geocryol. 2010, 32, 257-264.

15. Yang, J.P.; Ding, Y.J.; Chen, R.S. Comprehensive Research of Ecological Environment Change in The Yangtze-Yellow Rivers Source Regions; China Meteorological Press: Beijing, China, 2006; pp. 102-123.

16. Chen, J.S.; Tao, S.; Deng, B.S. Water Environmental Chemistry; Higher Education Press: Beijing, China, 1987; pp. 45-66.

17. Hou, S.G. Chemical characteristics of precipitation at the headwaters of the Urumqi River in the Tianshan Mountains. J. Glaciol. Geocryol. 2001, 23, 80-84.

18. Zhang, L.T.; Chen, J.S. The relationship between the composition of the major ion of river of China and regional natural factors. Sci. Geogr. Sin. 2000, 20, 236-240.

19. Gao, T.G.; Kang, S.C.; Zhang, Q.G. Major ionic Ffatures and their sources in the Nam Co Basin over the Tibetan Plateau. Environ. Sci. 2008, 29, 3009-3016.

20. Qin, J.H.; Huh, Y.; Edmond, J.M.; Du, G.; Ran, J. Chemical and physical weathering in the Min Jiang, a headwater tributary of the Yangtze River. Chem. Geol. 2006, 227, 53-69. [CrossRef]

21. Liu, F.J.; Conklin, M.H.; Shaw, G.D. Insights into hydrologic and hydrochemical processes based on concentration-discharge and end-member mixing analyses in the mid-Merced River Basin, Sierra Nevada, California. Water. Resour. Res. 2017, 53, 832-850. [CrossRef]

22. Gibbs, R.J. Mechanisms controlling world water chemistry. Science 1970, 170, 1088-1090. [CrossRef]

23. Xu, H.; Hou, Z.H.; An, Z.S. Major ion chemistry of waters in Lake Qinghai catchments, NE Qinghai-Tibet plateau, China. Quat. Int. 2010, 212, 35-43. [CrossRef]

24. Xia, X.H.; Zhang, L.T.; Chen, J.S. The effect of lithology and climate on major ion chemistry of the Yangtze River system. Acta Sci. Nat. Univ. Pekin. 2000, 36, 246-252.

25. Zhu, B.Q.; Yang, X.P. The ion chemistry of surface and ground waters in the Taklimakan Desert of Tarim Basin, western China. Chin. Sci. Bull. 2007, 52, 2123-2129. [CrossRef]

26. Karis, T.; Silvester, E.; Rees, G. Chemical regulation of alpine headwater streams during a storm event (Bogong High Plains, Victoria, Australia). J. Hydrol. 2016, 542, 317-329. [CrossRef]

27. Xiao, J.; Jin, Z.D.; Ding, H. Geochemistry and solute sources of surface waters of the Tarim River Basin in the extreme arid region, NW Tibetan Plateau. J. Asian Earth Sci. 2012, 54, 162-173. [CrossRef]

28. Yang, Q.; Xiao, H.; Zhao, L. Hydrological and isotopic characterization of river water, groundwater, and groundwater recharge in the Heihe River basin, northwestern China. Hydrol. Process. 2011, 25, 1271-1283. [CrossRef]

29. Galy, A.; France-Lanord, C. Weathering processes in the Ganges-Brahmaputra basin and the riverine alkalinity budget. Chem. Geol. 1999, 159, 31-60. [CrossRef]

30. Gaillardet, J.; Dupré, B.; Louvat, P. Global silicate weathering and $\mathrm{CO}_{2}$, consumption rates deduced from the chemistry of large rivers. Chem. Geol. 1999, 159, 3-30. [CrossRef]

31. Roy, S.; Gaillardet, J.; Allègre, C.J. Geochemistry of dissolved and suspended loads of the Seine River, France: Anthropogenic impact, carbonate and silicate weathering. Geochim. Cosmoschim. Acta 1999, 63, 1277-1292. [CrossRef]

32. Noh, H.; Huh, Y.; Qin, J.H. Chemical weathering in the Three Rivers region of Eastern Tibet. Geochim. Cosmoschim. Acta 2009, 73, 1857-1877. [CrossRef]

33. Meybeck, M. Atmospheric inputs and river transport of dissolved substances. In Dissolved loads of Rivers and Surface Water Quantity/Quality Relationships, Proceedings of A Symposium Held During The XVIIIth General Assembly of the International Union of Geodesy and Geophysics at Hamburg, Germany, 15-27 August 1983; IAHS (International Association of Hydrological Sciences): London, UK, 1983.

34. Tian, L.; Yao, T.; MacClune, K.; White, J.W.C.; Schilla, A.; Vaughn, B.; Vachon, R.; Ichiyanagi, K. Stable isotopic variations in west China: A consideration of moisture sources. J. Geophys. Res. Atmos. 2007, 112. [CrossRef]

35. Pu, T.; He, Y.Q.; Zhu, G.F. Hydrochemical characteristics of Three Rivers around Yulong Mountain in rainy season. Sci. Geogr. Sin. 2011, 31, 734-740.

36. Wang, Y.S.; Chen, X.X.; Zhang, M.N. Hydrochemistry and chemical weathering processes of Malian River basin. Earth Environ. 2018, 46, 15-22. 
37. Wu, W.H.; Yang, J.D.; Xu, S.J. Geochemistry of the headwaters of the Yangtze River, Tongtian He and Jinsha Jiang: Silicate weathering and $\mathrm{CO}_{2}$ consumption. Appl. Geochem. 2008, 23, 3712-3727. [CrossRef]

38. Fan, B.L.; Zhao, Z.Q.; Tao, F.X. Characteristics of carbonate, evaporite and silicate weathering in Huanghe River basin: A comparison among the upstream, midstream and downstream. J. Asian Earth Sci. 2014, 96, 17-26. [CrossRef]

39. Feng, F.; Li, Z.Q.; Zhang, M.J. Hydrochemical characteristics and controls of runoff at the headwaters of the Urumqi River, eastern Tianshan Mountain. Resour. sci. 2011, 33, 2238-2247.

40. Anderson, S.P.; Drever, J.I.; Humphrey, N.F. Chemical weathering in glacial environments. Geology 1997, 25, 399-402. [CrossRef]

(C) 2018 by the authors. Licensee MDPI, Basel, Switzerland. This article is an open access article distributed under the terms and conditions of the Creative Commons Attribution (CC BY) license (http:// creativecommons.org/licenses/by/4.0/). 